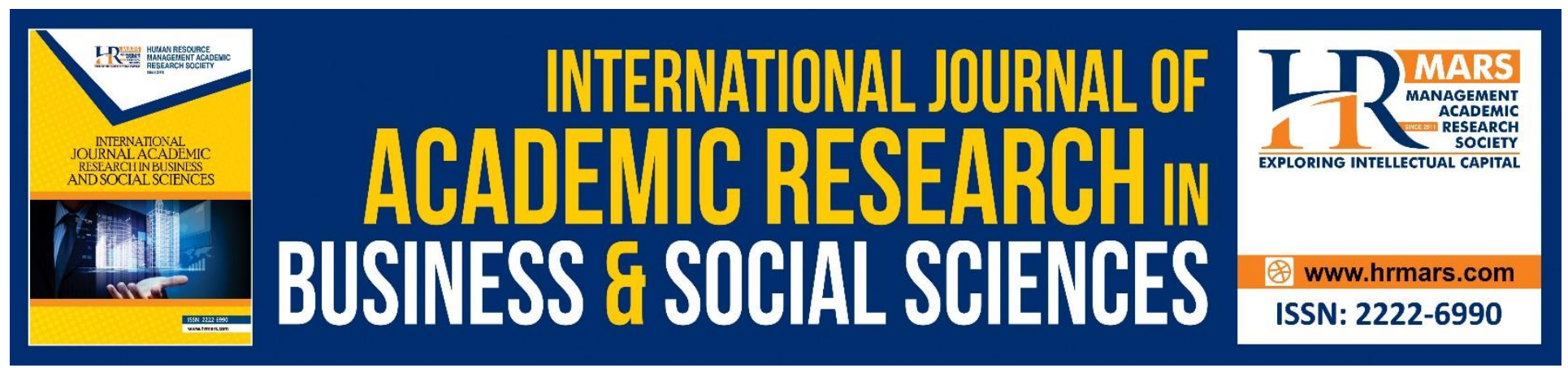

\title{
UTAUT Implementation of Cryptocurrency based Islamic Financing Instrument
}

\section{Ritchie Jay Cheng}

To Link this Article: http://dx.doi.org/10.6007/IJARBSS/v10-i9/7880

DOI:10.6007/IJARBSS/v10-i9/7880

Received: 06 June 2020, Revised: 10 July 2020, Accepted: 16 August 2020

Published Online: 27 September 2020

In-Text Citation: (Cheng, 2020)

To Cite this Article: Cheng, R. J. (2020). UTAUT Implementation of Cryptocurrency based Islamic Financing Instrument. International Journal of Academic Research in Business and Social Sciences. 10(9), 873-884.

\section{Copyright: (C) 2020 The Author(s)}

Published by Human Resource Management Academic Research Society (www.hrmars.com)

This article is published under the Creative Commons Attribution (CC BY 4.0) license. Anyone may reproduce, distribute, translate and create derivative works of this article (for both commercial and non-commercial purposes), subject to full attribution to the original publication and authors. The full terms of this license may be seen at: http://creativecommons.org/licences/by/4.0/legalcode

Vol. 10, No. 9, 2020, Pg. 873 - 884

Full Terms \& Conditions of access and use can be found at http://hrmars.com/index.php/pages/detail/publication-ethics 


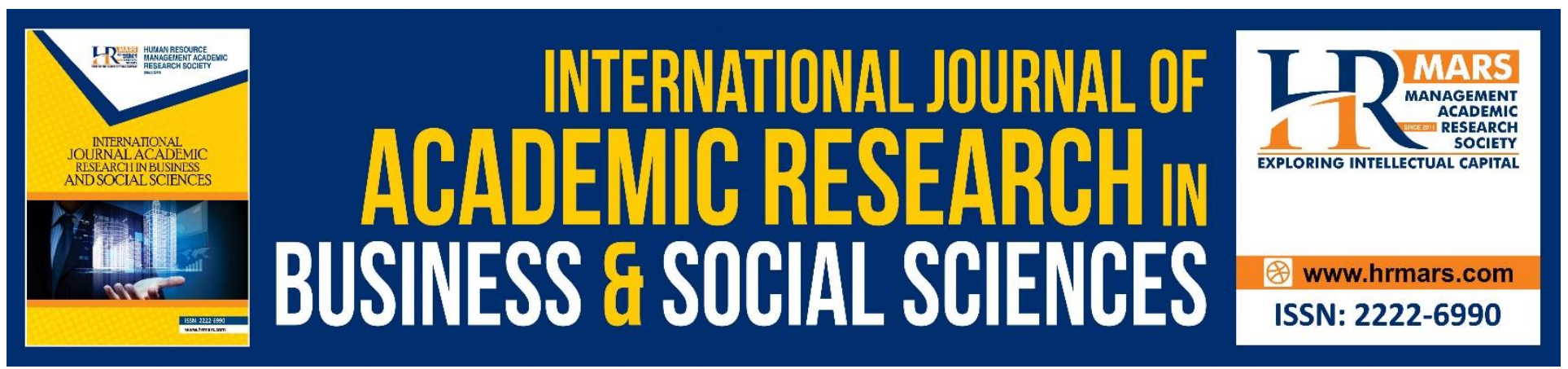

\title{
UTAUT Implementation of Cryptocurrency based Islamic Financing Instrument
}

\author{
Ritchie Jay Cheng \\ Labuan Faculty of International Finance, University Malaysia Sabah, Malaysia
}

\begin{abstract}
The recurrence of global financial crisis catalysed the advancement of the financial technology which in this study proposes conceptual model for Cryptocurrency based Islamic financing Instrument. The paper is an attempt in proposing the conceptual model of Unified Theory of Acceptance and Use of Technology (UTAUT) to determine factors influencing the adoption which derived from the literature review. Thus, the model proposes a direct relationship between variables of $\mathrm{FC}$ and $\mathrm{BI}$ and maintaining moderating factors of GEN and AGE while USE, EXP and VOL variables were removed. The paper expected to contribute to the development of a theoretical knowledge of UTAUT theory that expand the current limited studies on adoption of cryptocurrency based Islamic financing. The study also provides contribution to financial technology firms, academicians, regulators and practitioners on future work extension in applications in relation to Islamic instruments model adoption with end client. Nevertheless, the proposed conceptual model is set forth as the underlying approach for future empirical study validation in keeping with the technology momentum.
\end{abstract}

Keywords: FinTech, Blockchain, Cryptocurrency, Islamic Financing Instrument, UTAUT.

\section{Introduction}

The emergence of FinTech has disrupted the traditional finance ecosystem which seen as one of the technologies that would revolutionise finance industry. The term FinTech is the another phrase for financial technology which defined as financial innovation to intensify new business models, products, application and processes in the financial services (Kawai, 2016). Despite the fact that FinTech establishments have expanded rapidly, (Arner, Barberis \& Buckley, 2016; Mahomed \& Mohamad, 2017; McCarthy, 2015) revealed that the global financial crisis in the year 2008 probably serve as a stimulant to the growth of a new digital era in financial industry. This is in line with Arner, Barberis \& Buckley (2016) states the global financial crisis had a catalysing effect on the growth of the FinTech sector from the unintended consequences of post crisis regulatory reforms, the need of cost reduction, the lack of public trust on formal financial institutions and finally, the technology penetration.

For the last decades, financial industry has gone through numerous development of FinTech based innovations such as electronic fund transfers at the point-of-sale (EFTPOS), automated teller machine (ATM), Society for Worldwide Interbank Financial Telecommunication (SWIFT), Bankers' 
INTERNATIONAL JOURNAL OF ACADEMIC RESEARCH IN BUSINESS AND SOCIAL SCIENCES Vol. 10, No. 9, 2020, E-ISSN: 2222-6990 @ 2020 HRMARS

Automated Clearing Services (BACS), Clearing House Interbank Payments System (CHIPS), the establishment of NASDAQ, internet and mobile banking, Electronic Data Interchange (EDI), Bank Negara Malaysia Investment account platform (IAP) and finally, Blockchain payment technology of Cryptocurrency. While Islamic finance has not kept momentum in respect to technology adoption as opposed to conventional banking sector's, change is yet to happen through the intensified adoption of Cryptocurrency based Islamic financing. Without question, the most important factors for the success of technology acceptance is the users' adoption. Therefore, this paper proposes a conceptual model of Cryptocurrency based Islamic financing instrument which aims to understand the factors that can affect users' intention to adopt. The Unified Theory of Acceptance and Use of Technology (UTAUT) will be selected as a guiding principle in the research. This study will develop new understanding of the implementation of Cryptocurrency based Islamic financing and the factors that influence the users. Identifying the influence factors are important in predicting trend and identifying obstacles connecting to the preference of the said model.

\section{Literature Review}

\section{Blockchain Technology}

The concept of Blockchain is a form of shared distributed ledger that is distributed across and managed by peer-to-peer (P2P) networks to facilitates the process of recording a transaction and tracking assets in a business network. An asset can be tangible which is a house, a car, a land and cash or intangible as intellectual property such as patents, copyrights or branding. Virtually anything of value can be tracked and traded on a Blockchain network, reducing risk and cutting costs for all involved (Gupta, 2017).

It is worth noting that Blockchain works on the basis of large participants of computer with an IP address called nodes. Nodes can be anything that has an IP address such as computers. A node represents a single individual computer connected via network to verified transactions and passes on to the others nodes to reach consensus. Once all nodes reach consensus, the transactions are publicly broadcast to all nodes which the records are put into a block. This process is continuous, forming a chain of block with all records of transaction. All of the blocks are time stamped in current time and date that includes the previous time stamped blocks with each block reinforcing the ones before it (Nakamoto, 2008). Blocks added to the chain are immutable and it is a vital characteristic of a Blockchain. In the context of publicly shared transactions, it is in line with the Islamic teachings derived from the primary source of Quran which says,

$O$ ye who believe! When ye deal with each other, in transactions involving future obligations in a fixed period of time, reduce them to writing. Let a scribe write down faithfully as between the parties (Quran, 2:282).

Technically, Blockchain is a data structure characterized by a transaction scripting language (Porru, Pinna, Marchesi, \& Tonelli, 2017). Hence, all Blockchain support the deployment of smart contracts which it is also one of the four basic technical components in a Blockchain. As such, smart contract is the most used application in present day Blockchain (EYGM, 2017) and act as scribe with pre-agreed agreement that involve future obligations that execute autonomously when all party fulfils the pre-defined terms (Mcneal, 2018). These digital contracts are converted into codes and allowed to be run into a Blockchain that enable the exchange of tangible and intangible assets such 
INTERNATIONAL JOURNAL OF ACADEMIC RESEARCH IN BUSINESS AND SOCIAL SCIENCES Vol. 10, No. 9, 2020, E-ISSN: 2222-6990 @ 2020 HRMARS

as money, stock, shares and digital assets with time efficient, paperless, curtail lengthy process (Pratap, 2018), tamper proof (Lauslahti, Mattila, \& Seppälä, 2017), remove intermediaries, minimizing fraud while lowering transaction costs (Szabo, 1994).

As Cryptocurrency is only the first use case of Blockchain, Nakamoto (2008) created digital Peer-to-Peer (P2P) payment system called Bitcoin, a type of cryptocurrency that act as an electronic payment system, a mean of exchange, store of value, independent of any central authority that could be sent electronically in a secure, immutable and verifiable way (Church; Cowen, 2017). Technically, cryptocurrency are not a physical objects or digital files other than an entry in the Blockchain ledger. Therefore, possessing cryptocurrencies is purely owning a claim on a parcel of data recorded in the Blockchain. Currently, the regulation for Cryptocurrency had recognized and used two words to represent it, namely digital currency (BNM, 2018; Deakin \& Liu, 2018) and virtual currency (BSP, 2017; Japan, 2017; DFS, 2015; FATH, 2014). As such, Blockchain technology had wide variety of use cases across industries such as for Eradication of Hunger (United Nation, 2018), Digital Identities, Medical Solution (Bloomberg, 2019), Supply chains (Francisco \& Swanson, 2018), public governance (Kass, 2018) and many more.

In the context of Cryptocurrency based Islamic financing application, this P2P model connects borrowers and financiers via computer or smartphone to achieve greater financial inclusivity especially connecting people instantly who live in a rural region and bypassing intermediaries at a fraction of cost. In addition, borrowers without formal identification would acquire a digital identity via smartphones by leveraging the Blockchain. In addition, funds are raised through the issuance of. Financiers' are free to trade amongst themselves using the acquired Cryptocurrency in the said Islamic financing instrument platform. In the same way, all transactions data are recorded and shared in the Blockchain for audit and transparency. 
INTERNATIONAL JOURNAL OF ACADEMIC RESEARCH IN BUSINESS AND SOCIAL SCIENCES Vol. 10, No. 9, 2020, E-ISSN: 2222-6990 @ 2020 HRMARS

\section{Cryptocurrency based Islamic Financing Instrument}

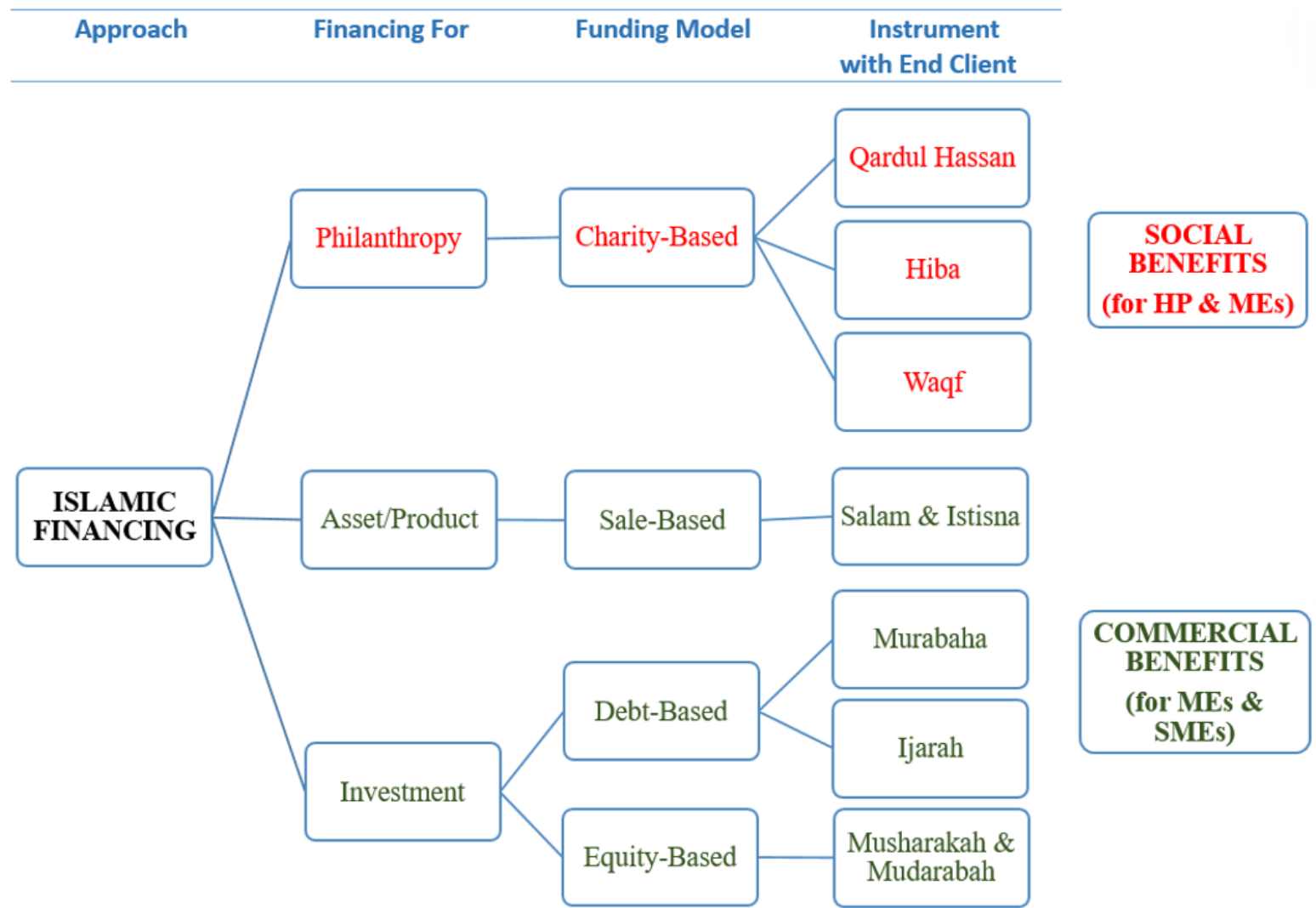

Figure 1. Cryptocurrency based Islamic Financing Instrument Model

Islamic financing objectives is to facilitates financial services to anyone that in need of financial resources without incurring Riba (interest), Mysir (gambling) and Gharar (uncertainty). It is a righteous act of the principles of Muamalat (social transactions) in Islam which promotes just and fair economic dealings between parties. Therefore, a Shariah compliant instrument models must involve in Halal (permissible) financial transaction which stated by Asutay, Marzban \& Boseli (2014) to transact socially responsible products whilst sharing the investment risks and without the involvement of prohibition elements. Hence, the model would propose future work extension in applications involving Islamic instrument variables namely the model adoptions with end client of Qardul Hassan, Hiba, Waqf, Salam, Istisna, Murabaha, ljarah, Musyarakah or Mudarabah as in the Cryptocurrency based Islamic financing context. The Figure 1 shows the instruments model are categorised into two section namely Hardcore Poor (HP) and Micro Enterprises (MEs) highlighted in red while both MEs and Small Medium Enterprises (SMEs) in green.

\section{UTAUT Theory}

This study proposes a conceptual model of the users' intention to adopt Cryptocurrency based Islamic financing on the selected UTAUT model. From the word itself, Cryptocurrency is an IT-driven innovation, thus, an IT adoption model is selected in this research. In this matter, Venkatesh et al. (2003) have carry out a review and found 8 models of IT adoption namely Theory of Reasoned Action(TRA), Technology Acceptance Model(TAM), Theory of Planned Behaviour(TPB), Combined 
INTERNATIONAL JOURNAL OF ACADEMIC RESEARCH IN BUSINESS AND SOCIAL SCIENCES Vol. 10, No. 9, 2020, E-ISSN: 2222-6990 @ 2020 HRMARS

TAM and TPB(C-TAMTPB), Motivational Model(MM), Model of PC utilization(MPCU), Innovation Diffusion Theory(IDT) and Social Cognitive Theory (SCT). As a result, Venkatesh et al. (2003) combined these 8 models to form a new framework named the UTAUT model.

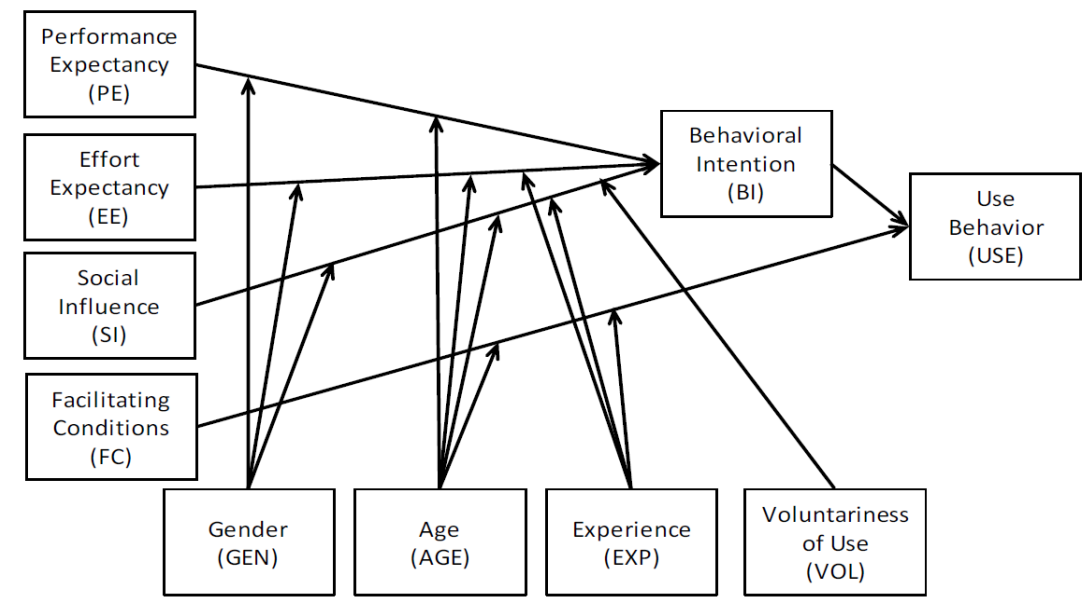

Figure 2. UTAUT Model (Venkatesh et al., 2003)

Hence, the integration of these 8 theories resulted in variance between $17 \%$ and $53 \%$ in user intentions to use IT. Remarkably, UTAUT was empirically tested using original data from four organizations and found to outperform the 8 models with a variance (adjusted $R^{2}$ ) of 69\%. UTAUT was then cross-validated using new data from an additional two organizations with similar results with a variance (adjusted $R^{2}$ ) of $70 \%$. Venkatesh et al. (2003) further stated that these tests provide strong empirical support for UTAUT that posits three direct determinants namely Performance Expectancy (PE), Effort Expectancy (EE), Social Influence (SI) of the behavioural intention to use. Similarly, there are two direct determinants which are Behavioural Intention (BI) and Facilitating Conditions (FC) of the usage behaviour (USE). Significant moderating influences of Gender (GEN), Age (AGE), Experience (EXP) and Voluntariness of Use (VOL) were confirmed as integral features of UTAUT which are shown in figure 2.

Therefore, UTAUT model is selected due to its high in variance value of usage intention, an improvement compared to other models. Moreover, Williams, Rana \& Dwivedi (2015) examined the existing 174 articles on UTAUT model and empirically illustrate the soundness of UTAUT as methodology in explaining the individual acceptance of technology that use in a variety of organizations, geographies and applications. Likewise, the independent variable of Performance expectancy (PE) and behavioural intention (BI) qualified for the best predictor category. Additionally, Gruzd, Staves \& Wilk (2012) found that the determinants of UTAUT were a useful starting point in analysing scholarly behavioural intention (BI) of social media usage. In contrast, the theoretical origination of UTAUT derived from the 8 technology acceptance theories are shown in table 1. 
INTERNATIONAL JOURNAL OF ACADEMIC RESEARCH IN BUSINESS AND SOCIAL SCIENCES Vol. 10, No. 9, 2020, E-ISSN: 2222-6990 @ 2020 HRMARS

Table 1. Theoretical Origination of UTAUT (Francisco \& Swanson, 2018)

\begin{tabular}{|c|c|c|c|}
\hline$\#$ & Theory & Source & Description \\
\hline 1 & $\begin{array}{l}\text { The Theory of Reasoned } \\
\text { Action (TRA) }\end{array}$ & Ajzen \& Fishbein & $\begin{array}{l}\text { TRA is used to predict individual behavior based on } \\
\text { pre-existing attitudes and intentions }\end{array}$ \\
\hline 2 & $\begin{array}{l}\text { The Technology Acceptance } \\
\text { Model (TAM) }\end{array}$ & Davis & End user use and acceptance model \\
\hline 3 & $\begin{array}{l}\text { The Theory of Planned } \\
\text { Behavior (TPB) }\end{array}$ & Ajzen & $\begin{array}{l}\text { TPB is the first model to mention psychological factors } \\
\text { related to technology acceptance }\end{array}$ \\
\hline 4 & $\begin{array}{l}\text { A combined TBP/TAM } \\
\text { (C-TAMTPB) }\end{array}$ & Taylor and Todd & $\begin{array}{l}\text { These authors added two factors (subjective norm and } \\
\text { perceived behavioral control) to TAM which gave a } \\
\text { more complete test of important determinants of } \\
\text { technology usage }\end{array}$ \\
\hline 5 & $\begin{array}{l}\text { The Model of PC } \\
\text { Utilization (MPCU) }\end{array}$ & Thompson & $\begin{array}{l}\text { A competing perspective to TRA and TPB used to } \\
\text { predict usage behavior rather than intention to use }\end{array}$ \\
\hline 6 & $\begin{array}{l}\text { Innovation Diffusion } \\
\text { Theory (IDT) }\end{array}$ & Rogers & $\begin{array}{l}\text { DIT describes how technological innovation moves from } \\
\text { invention to widespread useage }\end{array}$ \\
\hline 7 & Social Cognitive Theory (SCT) & Bandura & $\begin{array}{l}\text { Stipulates environmental influences (e.g., social } \\
\text { pressures) or unique personal factors (e.g., Personality) } \\
\text { are equally significant in determining behavior }\end{array}$ \\
\hline 8 & The Motivational Model (MM) & Davis & $\begin{array}{l}\text { The core constructs of the theory are extrinsic and } \\
\text { intrinsic motivation }\end{array}$ \\
\hline
\end{tabular}

In particular, review of IT adoption model necessitated the need to modify the constructs of UTAUT model in Cryptocurrency context. In this regard, this paper introduces Islamic financing instrument model for the development of Cryptocurrency adoption in the Islamic context. In this matter, the modification of UTAUT is in conjunction with the recommendation by Venkatesh \& Davis (2000) which suggest further extension of models of technology acceptance by explicitly develop understanding factors that influences users' adoption. This can be performed by modifying the model by making adjustment on the constructs to predict the behavioural intention.

\section{The Conceptual Model}

The conceptual model in the figure 3 presents the theoretical guidance for the adoption of Cryptocurrency based Islamic financing. The UTAUT conceptual model in this research demonstrates four main effects for end adoption which are maintained and proven to be reliable constructs in prior research namely the PE, EE, SI and FC (Williams et al., 2015). 


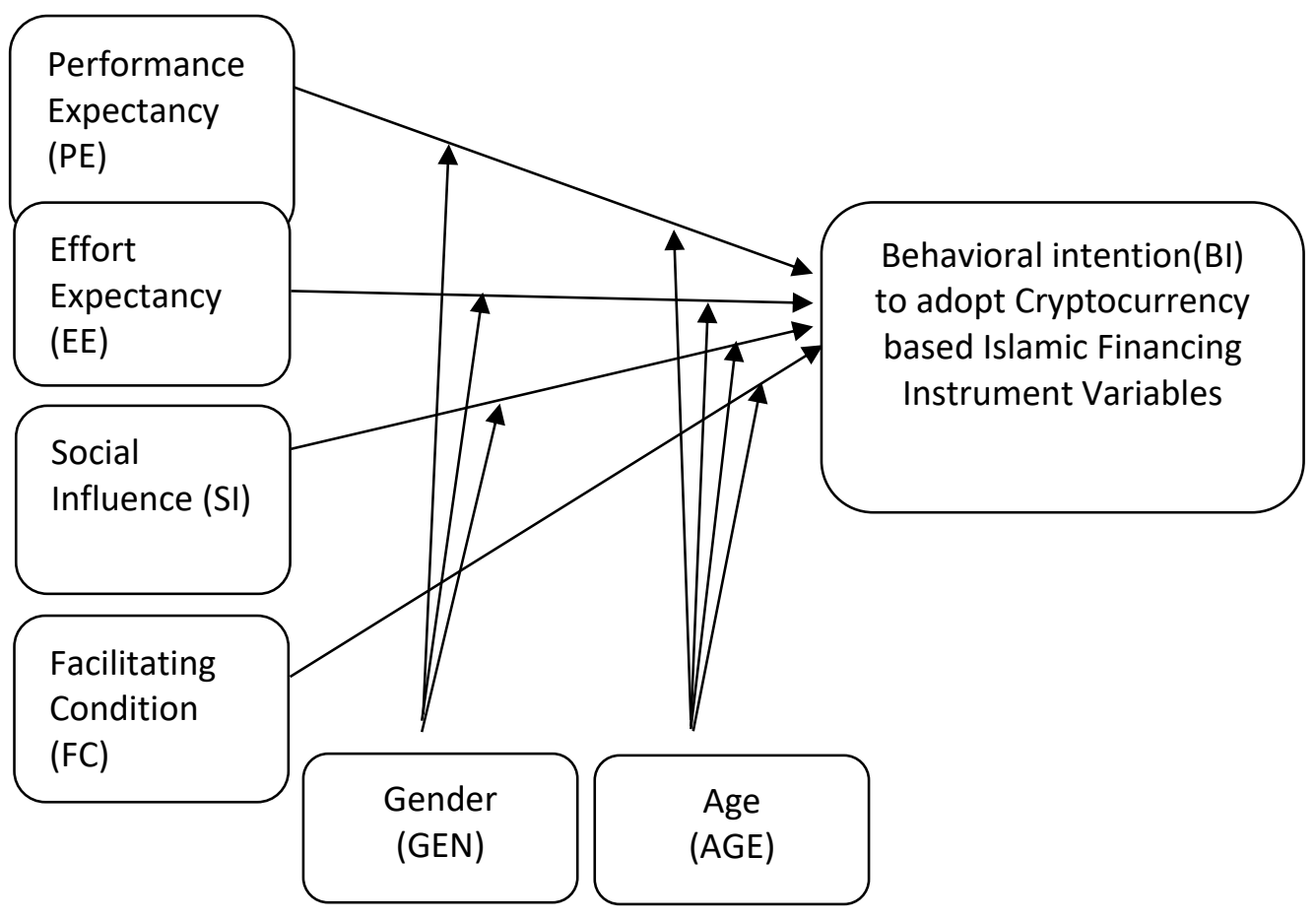

Figure 3. Conceptual Model

\section{Performance Expectancy (PE)}

The determinant of PE is defined as the degree to which an individual believes that using the system will help him or her to attain gains in a job performance (Venkatesh et al., 2003). PE is derived from the 5 constructs combination which are perceived usefulness (TAM), extrinsic motivation (MM), jobfit (MPCU), relative advantage (IDT) and outcome expectations (SCT). As such, PE remains the strongest predictor of intention within these combination of 5 constructs and continues to be significant at all points of measurement in both voluntary and mandatory settings (Venkatesh et al., 2003). Similarly, Zhou, Lu, \& Wang (2010) established that PE, SI, FC and task technology fit have significant effects on user adoption. As for the moderating effect, gender and age influences PE on behavioural intention such that the effect will be higher for men and specifically for younger men (Venkatesh et al., 2003).

\section{Effort Expectancy (EE)}

The determinant of EE is defined as the degree of ease associated with use of the system. EE captures 3 constructs from the existing models particularly the perceived ease of use (TAM), complexity (MPCU) and ease of use (IDT). The EE was significant in both voluntary and mandatory usage contexts, albeit only significant for the first time usage period and becoming non-significant over extended time of usage (Venkatesh et al., 2003). Besides, Deng, Liu \& Qi (2011) found that PE and EE are significant predictors of the intention to use web based questions and answers services (WBQAS). As for the moderating effect, behavioural intention for EE influenced by gender, age and experience such that the effect will be higher for women, specifically younger women and at the early stages of experience (Venkatesh et al., 2003). 
INTERNATIONAL JOURNAL OF ACADEMIC RESEARCH IN BUSINESS AND SOCIAL SCIENCES Vol. 10, No. 9, 2020, E-ISSN: 2222-6990 @ 2020 HRMARS

\section{Social Influence (SI)}

The determinant of $\mathrm{SI}$ is defined as the degree to which an individual perceives that it is important others believe he or she should use the new system. This includes the constructs from previous models namely the subjective norm (TAM2), social factors (MPCU) and image (IDT) (Venkatesh et al., 2003). Venkatesh et al., (2003) validates that SI constructs was not significant in voluntary contexts, although becomes significant when its use is mandated. Additionally, SI seems to be significant only in the initial stages of individual technology experience for mandatory settings and becoming nonsignificant with constant usage. As for the moderating effect, behavioural intention for SI influenced by gender, age, experience and voluntariness such that the effect will be higher for women, specifically older women in mandatory settings in the initial stages of experience.

\section{Facilitating Conditions (FC)}

FC is defined as the degree to which an individual believes that organizational and technical infrastructure exists to support use of the system. FC consists of the constructs for perceived behavioral control (TPB), facilitating conditions (MPCU) and compatibility (IDT) from previous models. The construct of FC is operated to include the technological and organizational environment aspects that are formed to remove barriers to use. Additionally, UTAUT model validation found that FC was significant in both voluntary and mandatory settings in the first usage. On top of that, FC are moderated by EE and when both PE and EE constructs are present, FC becomes non-significant in predicting intention (Venkatesh et al., 2003). However, the proposed conceptual model in which FC construct is directly towards to $\mathrm{BI}$ due to prior studies found that FC significant in predicting BI (Foon \& Fah, 2011; Venkatesh, Sykes \& Zhang, 2011). Additionally, Gupta, Dasgupta \& Gupta (2008) found that PE, EE, SI and FC positively influence the use of the ICT. As for the moderating effect, Venkatesh et al. (2003) cited that usage behavioural for FC influenced by age and experience such that the effect will be higher for older workers, specifically with increasing experience.

\section{Behavioural Intention (BI)}

The determinants for Behavioural Intention (BI) is defined as the measure to predict the performance of any voluntary act (Sheppard, Hartwick, \& Warshaw, 1988). In the UTAUT model, BI has a positive influence on use behaviour (USE) (Venkatesh et al., 2003). As for the dependent variable for USE is defined actual use behaviour of a specific system which is dominated by BI (Venkatesh et al., 2003). In this matter, variable of USE is removed and proposed direct relationship between $\mathrm{FC}$ towards $\mathrm{BI}$ due to the adjustment to fit current research scenario where actual usage of cryptocurrency based Islamic financing do not exist yet. In short, table 2 shows the summary of UTAUT core constructs.

The direct relationship between FC and BI constructs is proposed to fit on the current study scenario where the actual usage of cryptocurrency based Islamic financing do not exist yet and for this reason, the variable of use behaviour (USE) is removed. As for the moderators, the moderating variable of EXP and VOL was dropped since Cryptocurrency based Islamic financing is a new topic in this study and does not require experiences. Although, Venkatesh et al. (2003) apply future, present and past $(\mathrm{T} 1, \mathrm{~T} 2, \mathrm{~T} 3)$ to determine experience, longitudinal research is not applicable in this study due to its incapability to identified the increasing user experience at different time periods. As for the moderating variable for $\mathrm{VOL}$, it is not relevant to the user choice context since voluntariness was a dummy variable used to separate the situational contexts of voluntary and mandatory use (Venkatesh et al., 2003). In the same vein, 
INTERNATIONAL JOURNAL OF ACADEMIC RESEARCH IN BUSINESS AND SOCIAL SCIENCES Vol. 10, No. 9, 2020, E-ISSN: 2222-6990 @ 2020 HRMARS

Table 2. UTAUT Independent Variable Summary (Adaptation from Venkatesh et al., 2003)

\begin{tabular}{|c|c|c|c|}
\hline Determinant & Definition & Constructs & $\begin{array}{l}\text { Model Contributing to } \\
\text { Constructs }\end{array}$ \\
\hline $\begin{array}{l}\text { Performance } \\
\text { Expectancy (PE) }\end{array}$ & $\begin{array}{l}\text { The degree to which an } \\
\text { individual believes that } \\
\text { using the system will } \\
\text { help him/her to attain } \\
\text { gains in a job } \\
\text { performance. }\end{array}$ & $\begin{array}{l}\text { 1.Perceived } \\
\text { Usefulness (PU) } \\
\text { 2.Extrinsic } \\
\text { motivation } \\
\text { 3.Job-fit } \\
\text { 4.Relative } \\
\text { advantage } \\
\text { 5.Outcome } \\
\text { expectations }\end{array}$ & $\begin{array}{l}\text { Technology Acceptance Model } \\
\text { (TAM, TAM2) and Combine } \\
\text { TAM-TPB (Theory of Planned } \\
\text { Behaviour) } \\
\text { Motivation Model (MM) } \\
\text { Model of PC Utilization (MPCU) } \\
\text { Innovation Diffusion Theory } \\
\text { (IDT) } \\
\text { Social Cognition Theory (SCT) }\end{array}$ \\
\hline $\begin{array}{l}\text { Effort Expectancy } \\
\text { (EE) }\end{array}$ & $\begin{array}{l}\text { The degree of ease } \\
\text { associated with use of } \\
\text { the system. }\end{array}$ & $\begin{array}{l}\text { 1.Perceived ease } \\
\text { of use } \\
\text { 2.Complexity } \\
\text { 3.Ease of use }\end{array}$ & $\begin{array}{l}\text { TAM, TAM2 } \\
\text { MPCU } \\
\text { IDT }\end{array}$ \\
\hline $\begin{array}{l}\text { Social Influence } \\
\text { (SI) }\end{array}$ & $\begin{array}{l}\text { The degree to which an } \\
\text { individual perceives that } \\
\text { it is important others } \\
\text { believe he or she should } \\
\text { use the new system. }\end{array}$ & $\begin{array}{l}\text { 1.Subjective } \\
\text { norm } \\
\text { 2.Social } \\
\text { factors } \\
\text { 3.Image }\end{array}$ & $\begin{array}{l}\text { TRA Theory of Reasoned } \\
\text { Action), TAM2, TPB/DTPB and } \\
\text { Combine TAM-TPB } \\
\text { MPCU } \\
\text { IDT }\end{array}$ \\
\hline $\begin{array}{l}\text { Facilitating } \\
\text { Conditions (FC) }\end{array}$ & $\begin{array}{l}\text { The degree to which an } \\
\text { individual believes that } \\
\text { organizational and } \\
\text { technical infrastructure } \\
\text { exists to support use of } \\
\text { the system. }\end{array}$ & $\begin{array}{l}\text { 1.Perceived } \\
\text { behavioural } \\
\text { control } \\
\text { 2. Facilitating } \\
\text { conditions } \\
\text { 3.Compatibility }\end{array}$ & $\begin{array}{l}\text { TPB/DTPB, Combine TAM-TPB } \\
\text { (MPCU) } \\
\text { (IDT) }\end{array}$ \\
\hline
\end{tabular}

the use of cryptocurrency based Islamic financing do not exist yet and therefore, there is no moderating effect between VOL and any other constructs. Therefore, GEN and AGE are maintained as moderating factors in the proposed conceptual model. 
INTERNATIONAL JOURNAL OF ACADEMIC RESEARCH IN BUSINESS AND SOCIAL SCIENCES Vol. 10, No. 9, 2020, E-ISSN: 2222-6990 @ 2020 HRMARS

\section{Conclusion}

The conceptual model of UTAUT in this paper seek to extant the theoretical knowledge by maintaining moderating factors of GEN-AGE and the direct relationship between FC-BI constructs in the Cryptocurrency context. This paper contributes towards the conceptual model which posit various unexplored connections in the Cryptocurrency based Islamic financing environment. Accordingly, the proposed conceptual UTAUT model may provide researcher opening to explore and focus on various Islamic instrument model adoption with end client as varaibles. As the advancement of the Financial technology, Cryptocurrency has emerged as one of the fastest growing payment technology globally postulate the need of an earlier study for Islamic finance to keep momentum in respect to technology adoption as opposed to conventional banking. The study presented is limited being that the conceptual model is only established on literature review. Following the limitation, researcher may opt for empirical validation on the proposed conceptual model but however for the time being, conceptual model can offer to develop an understanding of the concept quicker rather than cumulative steps as empirical research requires longer time to accumulate.

\section{References}

Arner, D., Barberis, J., \& Buckley, R. (2016). THE EVOLUTION OF FINTECH: A NEW POST-CRISIS PARADIGM? University of New South Wales Law Research Series. Retrieved from http://www.ssrn.com/link/UNSW-LEG.htm

Arner, D. W., Barberis, J., \& Buckley, R. P. (2016). 150 years of Fintech : An evolutionary analysis. The Finsia Journal of Applied Finance, (3), 22. Retrieved from https://www.finsia.com/docs/default-source/jassa-new/JASSA-2016-/jassa-2016-issue-3/jassa2016-iss-3-complete-issue.pdf?sfvrsn=82839b93_4

Asutay, M., Marzban, S., \& Boseli, A. (2014). Shariah-compliant Crowd Funding: An Efficient Framework for Entrepreneurship Development in Islamic Countries. Harvard Islamic Finance Forum 2014. https://doi.org/10.13140/RG.2.1.2696.1760

BNM. (2018). Anti-Money Laundering and Counter Financing of Terrorism ( AML / CFT ) - Digital Currencies ( Sector 6 ). Retrieved from http://amlcft.bnm.gov.my/document/PD Digital currency-v2.pdf

Deakin, M., \& Liu, S. (2018). New anti-money laundering and counter-terrorism financing laws. Retrieved from https://www.pwc.com.au/legal/assets/legaltalk/new-anti-money-launderingand-counter-terrorism-financing-laws-300118.pdf

Deng, S., Liu, Y., \& Qi, Y. (2011). An empirical study on determinants of web based question-answer services adoption. Online Information Review, 35(5), 789-798. https://doi.org/10.1108/14684521111176507

DFS. (2015). Chapter I. Regulations o the superintendent of financial services part 200. Virtual Currencies. Retrieved from https://www.dfs.ny.gov/docs/legal/regulations/adoptions/dfsp200t.pdf

EYGM Limited. (2017). EY research: initial coin offerings (ICOs). (December), 44. Retrieved from http://www.ey.com/Publication/vwLUAssets/ey-research-initial-coin-offeringsicos/\%24File/ey-research-initial-coin-offerings-icos.pdf

FATH. (2014). Virtual Currencies Key Definitions and Potential AML/CFT Risks. Retrieved from http://amlcft.bnm.gov.my/publication/M5_FATF-Virtual Currencies Key Definitions and Potential AMLCFT Risks.pdf 
INTERNATIONAL JOURNAL OF ACADEMIC RESEARCH IN BUSINESS AND SOCIAL SCIENCES Vol. 10, No. 9, 2020, E-ISSN: 2222-6990 @ 2020 HRMARS

Foon, Y. S., \& Fah, B. C. Y. (2011). Internet Banking Adoption in Kuala Lumpur: An Application of UTAUT Model. International Journal of Business and Management, 6(4), 161-167. https://doi.org/10.5539/ijbm.v6n4p161

Francisco, K., \& Swanson, D. (2018). The Supply Chain Has No Clothes: Technology Adoption of Blockchain for Supply Chain Transparency. MDPI Logistics. https://doi.org/10.3390/logistics2010002

Gruzd, A., Staves, K., \& Wilk, A. (2012). Connected scholars: Examining the role of social media in research practices of faculty using the UTAUT model. Computers in Human Behavior, 28(6), 2340-2350. https://doi.org/10.1016/j.chb.2012.07.004

Gupta, B., Dasgupta, S., \& Gupta, A. (2008). Adoption of ICT in a government organization in a developing country: An empirical study. Journal of Strategic Information Systems, 17(2), 140154. https://doi.org/10.1016/j.jsis.2007.12.004

Mahomed, Z., \& Mohamad, S. (2017). Crypto Mania:The Shariah Verdict. Retrieved from https://ikr.inceif.org/bitstream/INCEIF/2889/1/crypto_mania_ziyaad_shamsher.pdf

McCarthy, N. (2015). Americans Trust Tech Firms More Than Banks For Finance. Retrieved from https://www.forbes.com/sites/niallmccarthy/2015/06/24/americans-trust-tech-firms-morethan-banks-for-finance-infographic/\#666160d54e94

Nakamoto, S. (2008). Bitcoin: A Peer-to-Peer Electronic Cash System. Www.Bitcoin.Org, 9. https://doi.org/10.1007/s10838-008-9062-0

Sheppard, B. H., Hartwick, J., \& Warshaw, P. R. (1988). The Theory of Reasoned Action: A MetaAnalysis of Past Research with Recommendations for Modifications and Future Research. Journal of Consumer Research. https://doi.org/10.1086/209170

United Nation. (2018). Annual Report 2017 United Nations World Food Programme Innovation Accelerator. Retrieved from https://innovation.wfp.org/year-review-2017/docs/WFPinnovation-accelerator-2017-annual-report.pdf

Venkatesh, V., \& Davis, F. D. (2000). Theoretical extension of the Technology Acceptance Model: Four longitudinal field studies. Management Science, 46(2), 186-204. https://doi.org/10.1287/mnsc.46.2.186.11926

Venkatesh, V., Morris, M. G., Davis, G. B., \& Davis, F. D. (2003). USER ACCEPTANCE OF INFORMATION TECHNOLOGY: TOWARD A UNIFIED VIEW. MIS Quarterly, 27(3), 425-478. https://doi.org/0.2307/30036540

Venkatesh, V., Sykes, T. A., \& Zhang, X. (2011). "Just what the doctor ordered": A revised UTAUT for EMR system adoption and use by doctors. Proceedings of the Annual Hawaii International Conference on System Sciences, 1-10. https://doi.org/10.1109/HICSS.2011.1

Williams, M. D., Rana, N. P., \& Dwivedi, Y. K. (2015). The unified theory of acceptance and use of technology (UTAUT): a literature review. Journal of Enterprise Information Management, 28(3), 443-448. https://doi.org/10.1108/JEIM-09-2014-0088

Zhou, T., Lu, Y., \& Wang, B. (2010). Integrating TTF and UTAUT to explain mobile banking user adoption. Computers in Human Behavior, 26(4), 760-767.

https://doi.org/10.1016/j.chb.2010.01.013 